\title{
Risk Inequality and the Polarized American Electorate
}

\author{
PHILIPP REHM*
}

\begin{abstract}
Why has the American political landscape grown more partisan since the 1970s? This article provides a novel account of the determinants of partisanship. The author argues that partisanship is not only shaped by the traditionally suggested socio-economic factors, but also by the uncertainty of future income (risk exposure): rich individuals facing a high degree of risk exposure (or poor people facing low risk exposure) are 'cross-pressured'; while their income suggests that they should identify with the Republicans, their income prospects make them sympathize with the Democrats. These two traits have overlapped increasingly since the 1970s. Those with lower incomes tend to be also those with higher risk exposure (risk inequality increased). This has led to a sorting of the American electorate: more citizens have become 'natural' partisans.
\end{abstract}

Since the 1970s, the United States has witnessed a process of sorting along partisan lines, at every level. Congress has been characterized by increasing party-line voting and a widening ideological gap between the parties. ${ }^{1}$ There has been an increasingly tight connection between political preferences and partisanship. ${ }^{2}$ More citizens are identifying strongly with a party, and fewer citizens are declaring themselves to be 'pure' independents. ${ }^{3}$ These developments have been well documented. ${ }^{4}$

* Department of Political Science, The Ohio State University (email: rehm.16@osu.edu). Earlier versions of this article have been presented at various occasions. The author thanks participants of the 'Research Workshop in Political Economy' (Harvard University), the 'Methods of Political Analysis' class at Harvard University, a seminar at the Max Planck Institute for the Study of Societies, the PostDoc as well as the Politics Seminar at Nuffield College, Oxford University, the 'Permanent Seminar series' at the Juan March Institute, and the Department of Government's seminar series at the University of Essex. Comments from John Aldrich, Jim Alt, Michele Belot, Ray Duch, Geoff Evans, Ben Goodrich, Peter Hall, Herbert Kitschelt, Scott Moser, Katherine Newman, David Rueda, David Soskice, Jim Stimson, Vera Troeger and Inés Valdez are gratefully acknowledged. Several of the Journal's reviewers have made excellent suggestions that have improved this article.

${ }^{1}$ John Aldrich, Why Parties? The Origin and Transformation of Political Parties in America (Chicago: Chicago University Press, 1995); Nolan McCarty, Keith T. Poole and Howard Rosenthal, Polarized America: The Dance of Ideology and Unequal Riches (Boston, Mass.: MIT Press, 2006), henceforth abbreviated to MPR.

${ }^{2}$ Larry M. Bartels, 'Partisanship and Voting Behavior, 1952-1996', American Journal of Political Science, 44 (2000), 35-50; Gary C. Jacobson, 'Party Polarization in National Politics: The Electoral Connection', in Jon R. Bond and Richard Fleisher, eds, Polarized Politics: Congress and the President in a Partisan Era (Washington, D.C.: CQ Press, 2000), pp. 9-30; Gary C. Jacobson, 'Partisan Polarization in Presidential Support: The Electoral Connection', Congress and the Presidency, 30 (2003), 1-36; Morris P. Fiorina, Samuel J. Abrams and Jeremy C. Pope, Culture War? The Myth of a Polarized America (New York: Pearson Longman, 2004).

3 John H. Aldrich, 'Political Parties in a Critical Era', American Politics Research, 27 (1999), 9-32.

${ }^{4}$ A particularly rich source is Jacobson, 'Partisan Polarization in Presidential Support'. For polarization at the mass level, see Paul DiMaggio, John Evans and Bethany Bryson, 'Have Americans' Social Attitudes Become More Polarized?' American Journal of Sociology, 102 (1996), 690-755; John H. Evans, 'Have Americans' Attitudes Become More Polarized? An Update', Social Science Quarterly, 84 (2003), 71-90. 

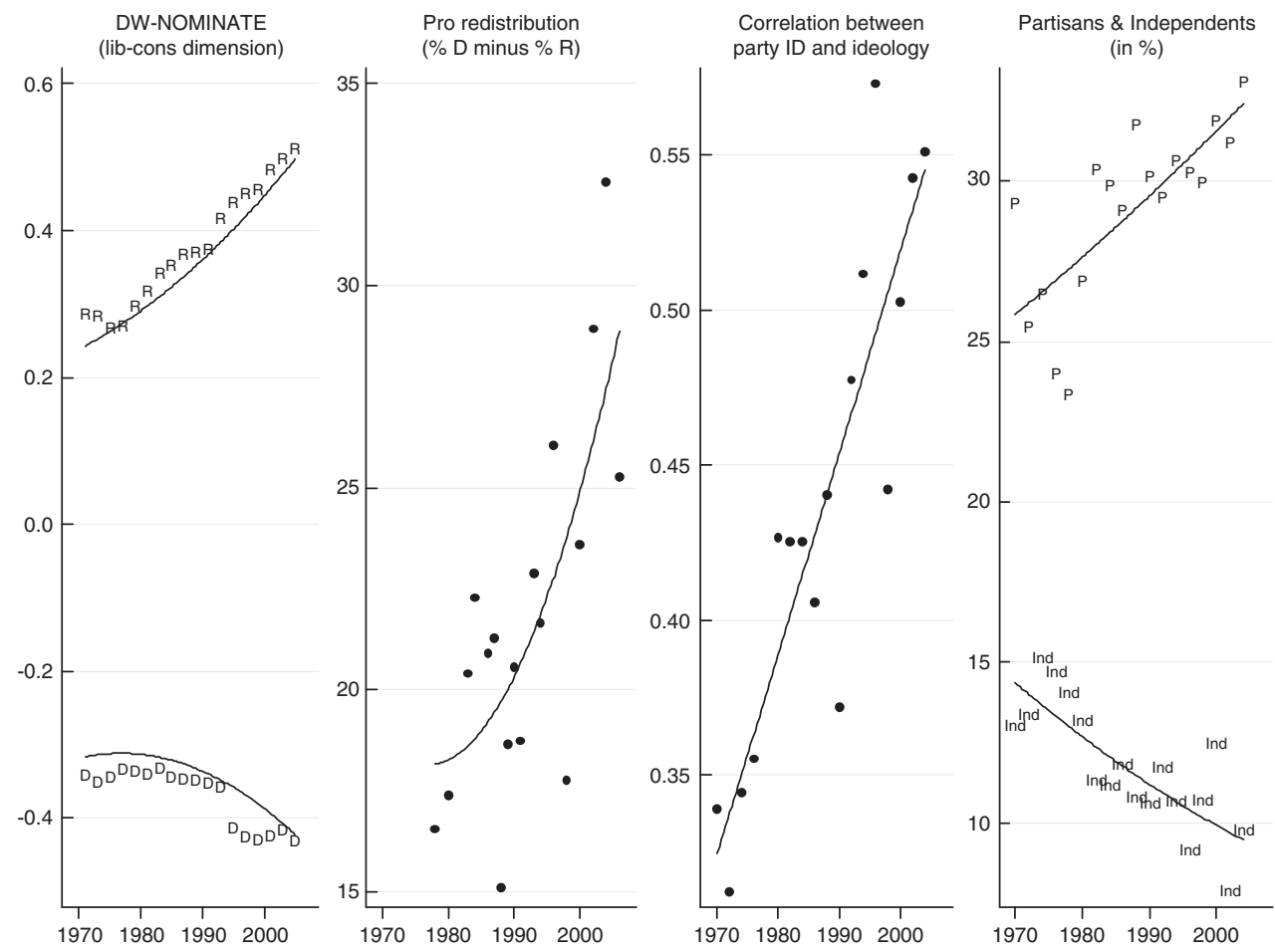

Fig. 1. Examples of sorting along partisan lines

Notes: The left-hand panel displays the median position of Democrats (D) and Republicans (R) in the House on the liberal-conservative (i.e. first) dimension of the DW-NOMINATE scores. These scores measure ideological locations from all the non-unanimous roll call votes cast in Congress. The liberal-conservative scale ranges from -1.0 (most liberal) to +1.0 (most conservative). The data are taken from http://voteview.com/pmediant.htm (accessed 2 January 2009). The second panel displays the share of Democrats who support redistribution (i.e. indicates that the 'government ought to reduce the income differences between rich and poor' - variable eqwlth in the GSS (see fn. 18 for details)) minus the share of Republicans who do so. Data are from the GSS cumulative file. The third panel displays correlation coefficients of party ID and ideology. The data are from the NES cumulative file. Party ID is measured on a seven-point scale [variable VCF0301 in the NES], from 1: strong Democrat to 7: strong Republican. Ideology measures respondents' self-placement on a liberal-conservative scale [VCF0801], where 0: most liberal and 97: most conservative. Data are weighted [VCF0009a]. The right-hand panel displays the percentage of people who classify themselves as 'Independent' (I) and the percentage of people who classify themselves as either 'strong Republicans' or 'strong Democrats' (P). Data sources and variables are as in the third panel. The solid lines are quadratic fits.

Figure 1 summarizes a few patterns. The left-hand panel in Figure 1 displays the median position of party members in the House on a liberal-conservative scale, based on DW-NOMINATE scores. ${ }^{5}$ A clear pattern of ideological sorting in the House emerges and the same pattern would be observable in the Senate. The second panel plots the percentage of Democrats who are in favour of redistribution, minus the percentage of Republicans who are. The residue sharply increases. The third panel shows the correlation

${ }^{5}$ Keith T. Poole and Howard Rosenthal, Congress: A Political-Economic History of Roll Call Voting (Oxford: Oxford University Press, 1997); McCarty, Poole and Rosenthal, Polarized America. 
between party identity and liberal-conservative ideology. Again, there is a clear trend towards increased ideological sorting. Finally, the right-hand panel in Figure 1 shows the percentages of party identifiers who classify themselves as independents or partisans (the sum of those who identify themselves as either strong Democrat or strong Republican). The percentage of independents decreased since the 1970s, while the percentage of strong partisans increased over the same time-period.

Why all this sorting along partisan lines? Recent scholarship has dealt with the question of whether these trends are driven by the elites or are due to 'popular demand'. ${ }^{6}$ It seems likely that developments both at the elite and at the mass level reinforced each other, leading to an upward spiral of increased partisanship: ${ }^{7}$ more ideologically sorted party elites confront citizens with more coherent alternatives. More partisan-driven citizens and constituencies give party elites incentives for purer partisan behaviour. The causes for increasing elite partisan behaviour are partially understood, while comparatively little is known about the mass level. This, then, is the main question this article addresses: what are the reasons for the sorting of citizens along partisan lines?

Or, differently put: what determines partisanship at the individual level and what has changed over the last four decades? The literature dealing with partisanship in the American electorate has a long tradition, ${ }^{8}$ and is quite contested. This article adopts a perspective of partisanship as a 'sum of preferences', i.e. it conceptualizes party identity (ID) as being endogenous to preferences. Different objective economic situations lead, at least indirectly via preferences, to different partisanship. The article, therefore, subscribes to a view which comes close to Fiorina's metaphor of partisanship as a 'running tally'.

In particular, I argue that adding an important factor to the usual suspects of determinants of partisanship offers new insights into the observed sorting along partisan lines. I apply a simple yet powerful prediction from the social insurance literature: that not only an individual's income, but also her income prospects (risk exposure), shape political preferences. Since, as I show, income and risk exposure are important and independent determinants of partisanship, the joint distribution of these two traits (a concept I call 'risk inequality') is of central importance. It turns out that income and risk exposure

${ }^{6}$ William A. Galston and Pietro S. Nivola, 'Delineating the Problem', in Pietro S. Nivola and David W. Brady, eds, Red and Blue Nation? Characteristics and Causes of America's Polarized Politics (Washington, D.C.: The Brookings Institution and The Hoover Institution, 2006), pp. 1-47, at p. 19. Reviews can be found in Keiko Ono, 'Electoral Origins of Partisan Polarization in Congress: Debunking the Myth', Extensions (Fall 2005), 1-8; and Geoffrey C. Layman, Thomas M. Carsey and Juliana Menasce Horowitz, 'Party Polarization in American Politics: Characteristics, Causes, and Consequences', Annual Review of Political Science 9 (2006), 83-110.

7 Mark D. Brewer, 'The Rise of Partisanship and the Expansion of Partisan Conflict within the American Electorate', Political Research Quarterly, 58 (2005), 219-29.

${ }^{8}$ Recent reviews are Morris P. Fiorina, 'Voting Behavior', in Dennis C. Mueller, ed., Perspectives on Public Choice: A Handbook (Cambridge, Mass.: Cambridge University Press, 1997), pp. 391-414; Harold D. Clarke and Marianne C. Stewart, 'The Decline of Parties in the Minds of Citizens', Annual Review of Political Science, 1 (1998), 357-78; Morris P. Fiorina, 'Parties and Partisanship: A 40-Year Retrospective', Political Behavior, 24 (2002), 93-115; Richard Johnston, 'Party Identification: Unmoved Mover or Sum of Preferences?' Annual Review of Political Science, 9 (2006), 329-51.

${ }^{9}$ Morris P. Fiorina, 'Economic Retrospective Voting in American National Elections: A MicroAnalysis', American Journal of Political Science, 22 (1978), 426-43; Morris P. Fiorina, Retrospective Voting in American National Elections (New Haven, Conn.: Yale University Press, 1981); Morris P. Fiorina, 'Elections and the Economy in the 1980s: Short- and Long-Term Effects', in Alberto Alesina and Geoffrey Carlina, eds, Politics and Economics in the Eighties (Chicago: Chicago University Press, 1991), pp. 17-38. 
evolved from being fairly cross-cutting to being strongly reinforcing traits over the last few decades. This process of increasing 'risk inequality', I argue, led to a sorting process at the mass level: the share of citizens with economic traits that make them either 'natural' Democrats (those with low income and high risk exposure) or 'natural' Republicans (those with high income and low risk exposure) has risen steeply. In contrast, fewer and fewer citizens are cross pressured ('natural' Independents), i.e. have either a combination of low income and low risk exposure or high income and high risk exposure. Together with rising inequality, ${ }^{10}$ increasing risk inequality helps to explain the above-mentioned trends.

The article proceeds as follows. The next section details the theoretical framework. It explains why income and risk exposure are two central determinants of partisanship, and why their joint distribution is of interest. The section following after that presents evidence at the micro and macro levels, respectively. The final section discusses the findings' implications and limitations. The Appendix contains details of the data.

\section{THEORETICAL FRAMEWORK}

This article applies a simple but powerful insight from the social insurance literature ${ }^{11}$ to the partisanship literature: that individuals' preferences are shaped not only by their current income but also by their income prospects (risk exposure). In particular, poor as well as riskexposed individuals should support redistributional policies (and hence left parties), because these policies help them today or insure them against the risk of being poor in the future.

This insight is very intuitive. If a person expects to be poor in the future (i.e. that person's risk exposure is high), that person should support policies and parties for the poor. In contrast, if one expects to be rich in the future (risk exposure is low), one should support policies and parties tailored towards the rich. This logic can be formalized relatively easily. ${ }^{12}$ The critical assumptions required to arrive at the results are that individuals are risk averse; that policy instruments are somewhat sticky; and that preferences are formed in a state of uncertainty about the future (risk exposure).

Consistent with the view that partisanship is the sum of policy preferences, it can be shown that redistributive policy preferences map onto partisan preferences (see the second

10 McCarty, Poole and Rosenthal, Polarized America.

11 Hal R. Varian, 'Redistributive Taxation as Social Insurance', Journal of Public Economics, 14 (1980), 49-68; Hans-Werner Sinn, 'A Theory of the Welfare State', Scandinavian Journal of Economics, 97 (1995), 495-526; Hans-Werner Sinn, 'Social Insurance, Incentives and Risk Taking', International Tax and Public Finance, 3 (1996), 259-80; Nicholas Barr, The Welfare State as Piggy Bank (Oxford: Oxford University Press, 2001); Torben Iversen and David Soskice, 'An Asset Theory of Social Policy Preferences', American Political Science Review, 95 (2001), 875-95; Karl O. Moene and Michael Wallerstein, 'Inequality, Social Insurance, and Redistribution', American Political Science Review, 95 (2001), 859-74; Nicholas Barr, The Economics of the Welfare State, 4th edn (Oxford: Oxford University Press, 2004). On the importance of social risk for politics, see the seminal contribution by Isabela Mares, The Politics of Social Risk: Business and Welfare State Development (Cambridge, Mass.: Cambridge University Press, 2003).

12 Brent Kreider, 'Income Uncertainty and Optimal Redistribution', Southern Economic Journal, 69 (2003), 718-25. A more general model can be found in Allan Drazen, Political Economy in Macroeconomics (Princeton, N.J.: Princeton University Press, 2000), pp. 315-17. Prominent contributions making use of a similar logic include Thomas Piketty, 'Social Mobility and Redistributive Politics', Quarterly Journal of Economics, 110 (1995), 551-84; Alberto Alesina, Edward Glaeser and Bruce Sacerdote, 'Why Doesn't the United States Have a European-Style Welfare State?' Brookings Papers on Economic Activity, 2 (2001), 187-254; Roland Bénabou and Efe A. Ok, 'Social Mobility and the Demand for Redistribution: The POUM Hypothesis', Quarterly Journal of Economics (May 2001), 447-87. 
panel in Figure 1 and the next section). Hence, I hypothesize that low-income as well as riskexposed individuals not only have pro-redistributive policy preferences but also left partisan preferences. Assuming that the Democratic party is more in favour of redistributional policies than the Republican party, people worried about their economic situation today and in the future should affiliate with the Democrats. ${ }^{13}$ In contrast, those who are rich today and/or expect to be rich in the future should affiliate with the Republicans.

The two traits influencing social policy and partisanship just mentioned - income and risk exposure - can, in principle, work against each other and cross-pressure individuals. ${ }^{14}$ Someone with high income but also high risk exposure is likely to be fairly moderate in her redistributional and partisan preferences, like someone with low income and low risk exposure. These cross-pressured voters should be 'natural' Independents (conservative Democrats or liberal Republicans, just like cross-pressured members of Congress). In contrast, an individual with consistent traits should be fairly extreme on redistributional and partisan preferences - a 'natural' partisan. Voters with low income and high risk exposure can be expected to be 'natural' Democrats (liberal Democrats), while voters with high income and low risk exposure are 'natural' Republicans (conservative Republicans). ${ }^{15}$

The suggested micro-level mechanism has macro-level implications as well. It is the joint distribution of income and risk exposure ('risk inequality') that will tell us something about the expected distribution of policy and partisan preferences. In particular, the joint distribution will determine the relative size of the aforementioned groups ('natural' Democrats, 'natural' Republicans and 'natural' Independents). As a hypothetical example, imagine a society in which risk exposure is disproportionally located at the upper end of the income scale. In contrast, poor individuals would have a particularly low degree of risk exposure. Since income and risk exposure are cross-cutting traits, this society would have a lot

13 There is an interesting connection to the economic voting literature. One could say that people's egocentric (or pocket-book) calculus of voting (or partisanship) is both retrospective (current income) and prospective (income prospects). The analogy to this article's argument would be that the expectation of being poor in the future makes one affiliate with the Democrats.

${ }^{14}$ Thinking about social policy preferences as shaped by the two traits of income and risk exposure can be useful in studying a range of phenomena. Assume that people fall into one of four categories: (i) low income-high risk (ii) low income-low risk (iii) high income-low risk (iv) high income-high risk. Depending on which cell they inhabit, individuals should have a higher or lower demand for redistribution and/or insurance. Depending on the relative population of these cells (which will vary across policy domain, over time, and across countries), we should observe more or less encompassing support for social policies. In particular, 'cross-class coalitions' should be most likely in situations in which the high income-high risk cell (and perhaps the low income-high risk cell) is relatively large. In contrast, social policy should be a more contested issue when the two traits are reinforcing (only the low income-high risk and high income-low risk cells are populated).

${ }^{15}$ This is obviously a radical simplification. Partisanship is a highly complex phenomenon and this article narrowly focuses on some aspects. The language of 'natural' independents and partisans is used for the sake of clarity. One immediate complication is that it is conceivable that some voters drop out of this scheme altogether: if individuals do not perceive a link between their policy preferences and the policy options the two parties offer, they may turn their backs on politics altogether (or perhaps classify themselves as 'Independents'). Conceptually, individuals with extreme policy preference should be most akin to political alienation of that sort (i.e. the 'natural' Democrats or the 'natural' Republicans). This has two implications. First, we can think of the American electorate as consisting of four groups: 'natural' Democrats, 'natural' Independents, 'natural' Republicans, and the 'alienated'. Secondly, the group of Independents can be expected to be quite heterogeneous since it may be made up of 'natural' Independents as well as individuals with such extreme policy preferences that they do not seem to be served by the two major parties. I will return to this point below. 
of cross-pressured, i.e. moderate, individuals in its electorate, namely many rich people with disproportional risk exposure and many poor people with very low risk exposure. As a more realistic example, imagine a society in which risk exposure is concentrated among the poor, while the rich have rosy income prospects. This society, in which income and risk exposure are reinforcing traits, would be divided on redistributional issues and its electorate would have large groups of 'natural' partisans. In the next section, I will show that income and risk exposure in America have become increasingly reinforcing traits over the last four decades. This, I argue, explains the increasing sorting along partisan lines.

\section{EVIDENCE}

\section{The Micro Level}

To explore whether redistributional preferences translate into partisanship, I employ the General Social Surveys (GSS). ${ }^{16}$ Partisanship is measured by a standard party ID survey item. ${ }^{17}$ I prefer to use partisanship (party ID) over vote choice or vote intention because this measure is likely to be less influenced by election-specific factors. Therefore, a comparatively slow-moving indicator like partisanship seems to be a good choice, and it also has the advantage of including the category of Independents. A respondent is classified as a 'Democrat' (Republican) if she identifies herself as 'strong', 'not very strong' or 'independent, close to' Democrat (Republican). Redistributional preferences are captured by a dummy variable for respondents who indicate that the 'government ought to reduce the income differences between rich and poor'. ${ }^{18}$ That variable maps closely onto partisan

16 James Allan Davis and Tom W. Smith, General Social Surveys, 1972-2006 (Machine-Readable Data File, 2nd Release October) (Chicago, Ill.; Storrs, Conn.: Principal Investigator, James A. Davis; Director and Co-Principal Investigator, Tom W. Smith; Co-Principal Investigator, Peter V. Marsden; Sponsored by National Science Foundation. - NORC ed.- Chicago: National Opinion Research Center (producer); Storrs, Conn.: The Roper Center for Public Opinion Research, University of Connecticut (distributor), 2008). I am using the GSS and not the National Election Studies (NES) for reasons that become clear below. I will discuss robustness checks at the end of this subsection. More details on the data can be found in the Appendix.

17 Respondents were asked the following question(s): 'Generally speaking, do you usually think of yourself as a Republican, Democrat, Independent, or what?' If they answered 'Republican' or 'Democrat', they were asked: 'Would you call yourself a strong (Republican/Democrat) or not very strong (Republican/ Democrat)?' If, instead, the respondent answered 'independent', 'no preference', or 'other', the follow-up question reads: 'Do you think of yourself as closer to the Republican or Democratic Party?' to which they could answer 'Republican', 'Democratic' or 'Neither'. The answers to these questions can be coded into a partisanship variable, classifying people into one of the following seven categories (otherwise, they are assigned a missing value and dropped from the analyses): 'Strong Democrat', 'Not very strong Democrat', 'Independent, close to Democrat', 'Independent', 'Independent, close to Republican', 'Not very strong Republican' and 'Strong Republican.' Despite some minor coding issues, this variable is comparable across time; see 'GSS Methodological Report 56' (http://webapp.icpsr.umich.edu/GSS/rnd1998/reports/m-reports/ meth56.htm).

${ }_{18}$ More precisely, the binary variable (employed in Figure 1 and the logit estimations below) equals one for answer categories 5 to 7 (and zero for categories 1 to 4) from the following survey item: 'Some people think that the government in Washington ought to reduce income differences between the rich and the poor, perhaps by raising the taxes of wealthy families or by giving income assistance to the poor. Others think that the government should not concern itself with reducing this income difference between the rich and the poor. Here is a card with a scale from 1 to 7. Think of a score of [7] as meaning that the government ought to reduce the income differences between the rich and the poor, and a score of [1] meaning that the government should not concern itself with reducing income differences. What score between 1 and 7 comes closest to the way you feel?' [Variable eqwlth in the GSS, reversed]. 
preferences, and increasingly so over time (see the second panel in Figure 1). As dependent variables I use these partisanship and redistributional items.

The central micro-level hypothesis to be tested is that income and risk exposure meaningfully shape individuals' policy and partisan preferences, controlling for other important determinants. I estimate models of the following form:

$$
\begin{gathered}
\text { redistribution }_{i t}=\beta_{r}\left(\text { RISK }_{i t}\right)+\gamma_{r}\left(I N C O M E_{i t}\right)+\delta_{r} X_{i t}+\phi_{r t}+\varepsilon_{r i t} \\
\text { partyID }_{i t}=\beta_{p}\left(R I S K_{i t}\right)+\gamma_{p}\left(I N C O M E_{i t}\right)+\delta_{p} X_{i t}+\phi_{p t}+\varepsilon_{p i t}
\end{gathered}
$$

where redistribution ${ }_{i t}$ and partyID ${ }_{i t}$ are (ordinal or binary) measures of redistributional preferences and partisanship for an individual $i$ at time $t ; R I S K_{i t}$ and $I N C O M E_{i t}$ are the key explanatory variables of interest, namely risk exposure and income; $X_{i t}$ is a set of characteristics of individual $i$; and $\phi_{t}$ is a set of year dummies.

How is risk exposure measured? The concept is about an individual's future income prospects. For almost all people, earnings from a job are a crucial source of their income (until they retire or drop out of the labour force for other reasons). For most of those participating in the labour market, this dependence on wage income is direct; it is indirect but nevertheless existing - for many of those not participating in the labour market. After all, people staying at home tend to be supported by other wage income earners.

A person's job - her occupation - is therefore of overwhelming importance when it comes to current income as well as future income. Therefore, I use 'occupational unemployment rates' as a proxy for risk exposure. ${ }^{19}$ For this measure, unemployment rates are calculated just like national unemployment rates but at detailed occupational levels (about 380 occupations). ${ }^{20}$ The data sources for these calculations are the March Annual Demographic Files from the Current Population Survey (CPS). These occupational unemployment rates are then merged into a public opinion survey, based on a respondent's occupation. ${ }^{21}$ Respondents in occupations with high (low) levels of unemployment rates have low (high) job security, and hence high (low) risk exposure. The higher an individual's occupational unemployment rate, the more risk-exposed that individual is.

The operationalization of income is straightforward: it is simply the (real) family income reported by a respondent. The $\delta$ s in the equation above capture the effect of the control variables. I follow McCarty, Poole and Rosenthal's (MPR) set up closely. ${ }^{22}$ In their book, they control for race, gender, education, age, region and church attendance. Exactly as in MPR, race and region are combined into two categorical variables: African-Americans and

19 These have been suggested in Philipp Rehm, 'Citizen Support for the Welfare State: Determinants of Preferences for Income Redistribution', in Discussion Paper SP II 2005-02, Wissenschaftszentrum Berlin [http://ssrn.com/paper=670761] (2005). Applications include Thomas Cusack, Torben Iversen and Philipp Rehm, 'Risks at Work: The Demand and Supply Sides of Government Redistribution', Oxford Review Economic Policy, 22 (2006), 365-89; Philipp Rehm, 'Ballot Boxing: Partisan Politics and Labor Market Risks', in Katherine Newman, ed., Laid Off, Laid Low: Political and Economic Consequences of Employment Insecurity (New York: Columbia University Press, 2008), pp. 108-27; Philipp Rehm, 'Risks and Redistribution: An Individual-Level Analysis', Comparative Political Studies, 42 (2009), 855-81; Philipp Rehm, 'Social Policy by Popular Demand', World Politics (forthcoming).

20 It goes without saying that these occupational unemployment rates could be further refined. For example, it would be interesting to have detailed estimates of unemployment duration, or regionally specific unemployment rates. But this runs into data limitation problems.

${ }^{21}$ It is therefore critical to have a public opinion dataset that includes detailed occupational information about respondents. The NES only includes detailed occupational variables from 1984 onwards. Therefore, the article relies on the GSS which includes detailed occupational variables from 1972 onward.

22 McCarty, Poole and Rosenthal, Polarized America. 
Southern non-African-Americans. Education is captured by two dummy variables ('some college' and 'at least college degree') and church attendance by a dummy variable for individuals attending church/synagogues at least 'once a month'. The operationalizations of gender (dummy for women) and age (in years) are obvious. These control variables are exactly the same as in MPR. One could include other controls, namely variables capturing respondents' employment or marital status. ${ }^{23}$ For robustness checks, additional estimations include controls for employment status (dummy for working part-time, dummy for being unemployed, dummy for not employed) and marital status (dummy for divorced).

Table 1 presents the logit estimates of three specifications of the model, pooling all observations across all years into one dataset (year dummies are included in the estimations, but not shown). The sample includes all the respondents for whom data were available on all the variables. The dependent variable in Models 1-3 is a dummy for redistributional preferences; the dependent variable in Models 4-6 is a dummy for Republican party ID. Models 1 and 4 display a specification that comes closest to MPR; Models 2 and 5 add the risk exposure variable; finally, Models 3 and 6 add control variables related to employment and marital status.

By and large, the results are as expected. Not surprisingly, the control variables perform roughly as could be expected from previous work, especially MPR. More importantly, this article's key explanatory variables - income and risk exposure - turn out to be statistically significant predictors of redistributional and partisan preferences. To give a sense of these variables' substantive impact, Figure 2 displays changes in predicted probabilities for redistribution (left panels) and partisanship (right panels) when simulating changes in risk exposure (top panels) and income (bottom panels).

Figure 2 allows one to read off changes in predicted probabilities based on various simulated changes in the explanatory variables. For example, the top-right panel suggests that the probability of affiliating with the Republican party decreases from about 0.39 to about 0.31 when changing a hypothetical person's risk exposure from minimum (close to 0 per cent) to about 12.4 per cent (which is the 90 th percentile in the data). The bottomright panel suggests that the same probability increases from about 0.29 to about 0.38 when changing income from minimum to p90. These are very large substantive effects and the effects would be even larger if changes throughout the variables' entire ranges were simulated. ${ }^{24}$

These estimations pool all observations across all years together. Figure 3 summarizes the results when the models are run year-by-year. There are no dramatic changes in the coefficients of income and risk exposure, and they tend to be statistically significant. This suggests that the impact of income and risk exposure on the dependent variables is more or less constant across time. In other words, the micro-level results (Table 1) are not an artefact of pooling.

${ }^{23}$ See, for example, Lena Edlund and Rohini Pande, 'Why Have Women Become Left-Wing? The Political Gender Gap and the Decline in Marriage', Quarterly Journal of Economics, 117 (2002), 917-61.

24 The substantive effects for the other variables are (simulated changes in parentheses): Redistribution (see Table 1, Model 2): age $(\min \rightarrow \max )$ : -0.12 ; female $(0 \rightarrow 1): 0.053$; some college $(0 \rightarrow 1):-0.007$; college $(0 \rightarrow 1)$ : -0.029 ; African-American $(0 \rightarrow 1)$ : 0.13 ; South and non-black $(0 \rightarrow 1):-0.047$; frequent church attendance $(0 \rightarrow 1)$ : -0.037 . Partisanship (see Table 1, Model 5): age $(\min \rightarrow \max )$ : 0.005 ; female $(0 \rightarrow 1)$ : -0.049 ; some college $(0 \rightarrow 1): 0.019$; college $(0 \rightarrow 1): 0.0202$; African-American $(0 \rightarrow 1):-0.296$; South and non-black $(0 \rightarrow 1)$ : 0.022 ; frequent church attendance $(0 \rightarrow 1): 0.086$. 
TA B LE 1 Determinants of Redistributional Preferences and Partisanship (Logit Estimations)

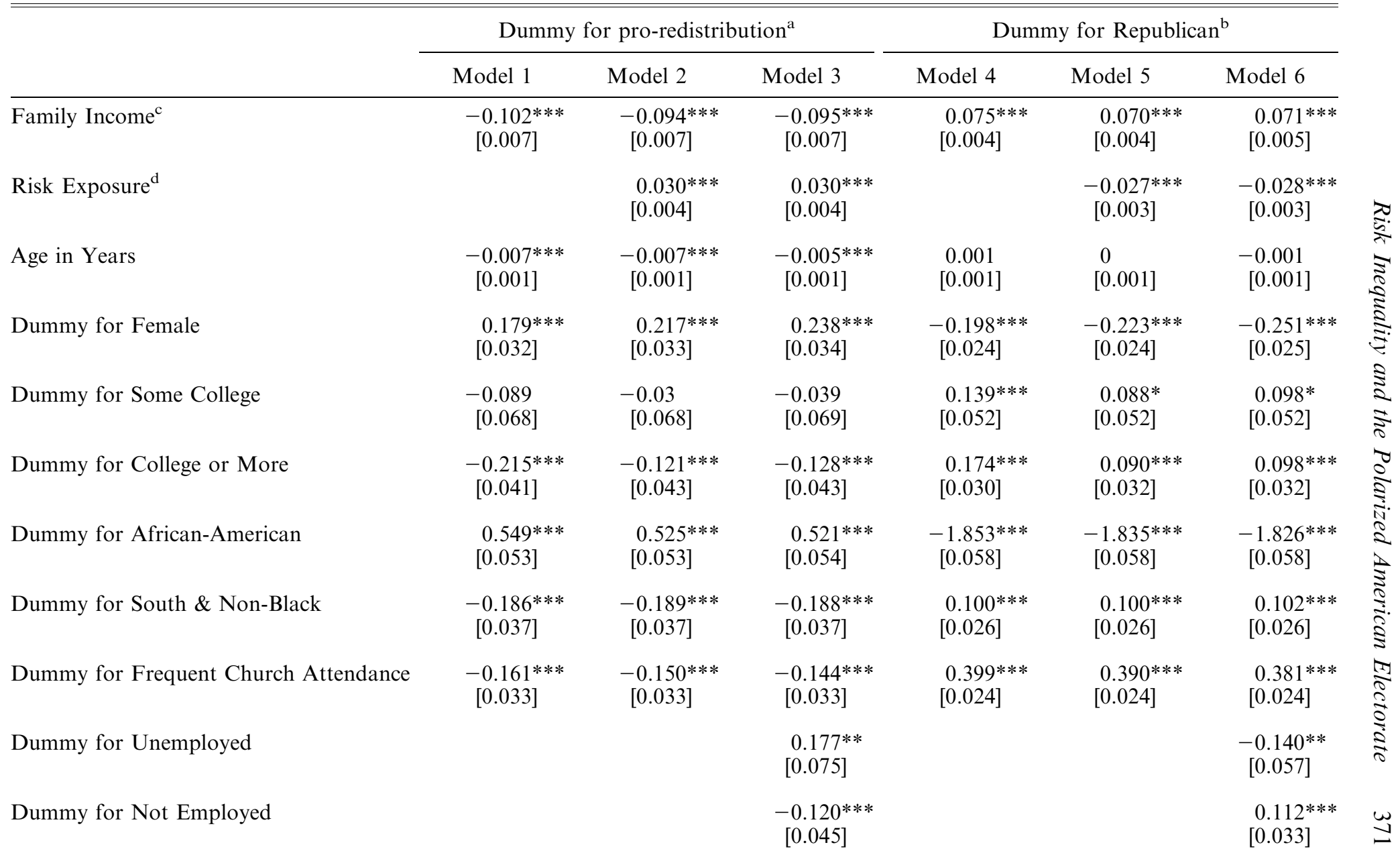


Dummy for pro-redistribution ${ }^{\mathrm{a}}$

Dummy for Republican ${ }^{\mathrm{b}}$

\begin{tabular}{|c|c|c|c|c|c|c|}
\hline & & & & \\
\hline & Model 1 & Model 2 & Model 3 & Model 4 & Model 5 & Model 6 \\
\hline Dummy for Working Part-Time & & & $\begin{array}{c}-0.01 \\
{[0.054]}\end{array}$ & & & $\begin{array}{l}0.091^{* *} \\
{[0.040]}\end{array}$ \\
\hline Dummy for Divorced & & & $\begin{array}{c}0.054 \\
{[0.049]}\end{array}$ & & & $\begin{array}{c}-0.073^{*} \\
{[0.038]}\end{array}$ \\
\hline Constant & $\begin{array}{l}0.599 \text { *** } \\
{[0.106]}\end{array}$ & $\begin{array}{l}0.343^{* * *} \\
{[0.111]}\end{array}$ & $\begin{array}{l}0.313^{* * * *} \\
{[0.107]}\end{array}$ & $\begin{array}{c}-1.244 * * * \\
{[0.080]}\end{array}$ & $\begin{array}{c}-1.023 * * * \\
{[0.083]}\end{array}$ & $\begin{array}{c}-0.990 * * * \\
{[0.084]}\end{array}$ \\
\hline $\begin{array}{l}\text { Year dummies } \\
\text { Observations } \\
\text { Pseudo } R^{2} \\
\text { Log Pseudolikelihood } \\
\text { Wald } \chi^{2} \text { (d.f.) }\end{array}$ & $\begin{array}{c}\text { Yes } \\
19,883 \\
0.04 \\
-13222.2 \\
735.9(25)\end{array}$ & $\begin{array}{c}\text { Yes } \\
19,883 \\
0.04 \\
-13188.6 \\
797.5(26)\end{array}$ & $\begin{array}{c}\text { Yes } \\
19,882 \\
0.04 \\
-13177.5 \\
819.1(30)\end{array}$ & $\begin{array}{c}\text { Yes } \\
40,170 \\
0.06 \\
-24672.2 \\
2052.5(33)\end{array}$ & $\begin{array}{c}\text { Yes } \\
40,170 \\
0.07 \\
-24622.7 \\
2113.5(34)\end{array}$ & $\begin{array}{c}\text { Yes } \\
40,165 \\
0.07 \\
-24600.9 \\
2139.4(38)\end{array}$ \\
\hline
\end{tabular}

Notes: Logit regressions, using weights. Shown are coefficients, with standard errors in brackets.

*Significant at $10 \% ; * *$ significant at $5 \% ; * * *$ significant at $1 \%$.

${ }^{a}$ Response categories 5-7 from variable with 1 ('no govt action') to 7 ('govt should reduce income differences') vs. categories 1-4.

${ }^{\mathrm{b}}$ Republican (independent, close to; not very strong; strong) vs. Democrat (independent, close to; not very strong; strong) and Independent.

${ }^{\mathrm{c}}$ In $10,0002005 \$$

${ }^{\mathrm{d}}$ Occupational unemployment rates are calculated inside the CPS at a standardized classification (ocdest), suggested by Peter B. Meyer and Anastasiya M. Osborne, 'Proposed Category System for 1960-2000 Census Occupations,' BLS Working Paper, no. 383 (2005), not gendered, top-coded at p98. 


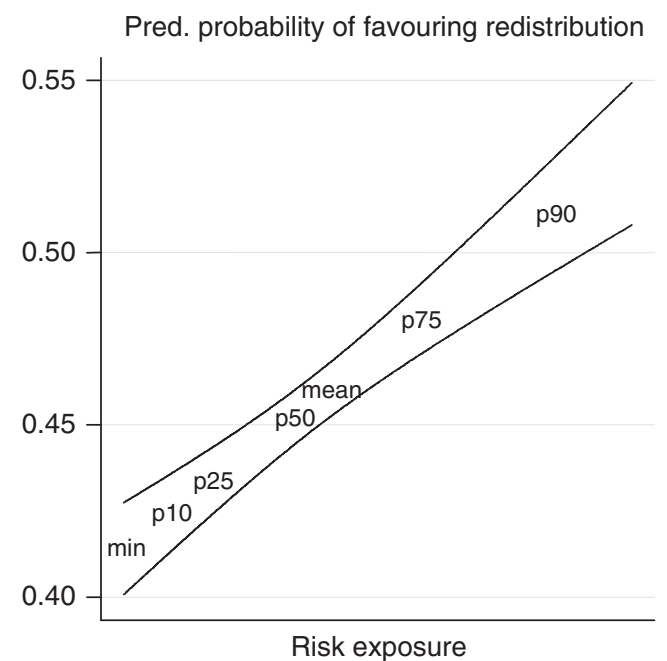

Pred. probability of affiliating Republican
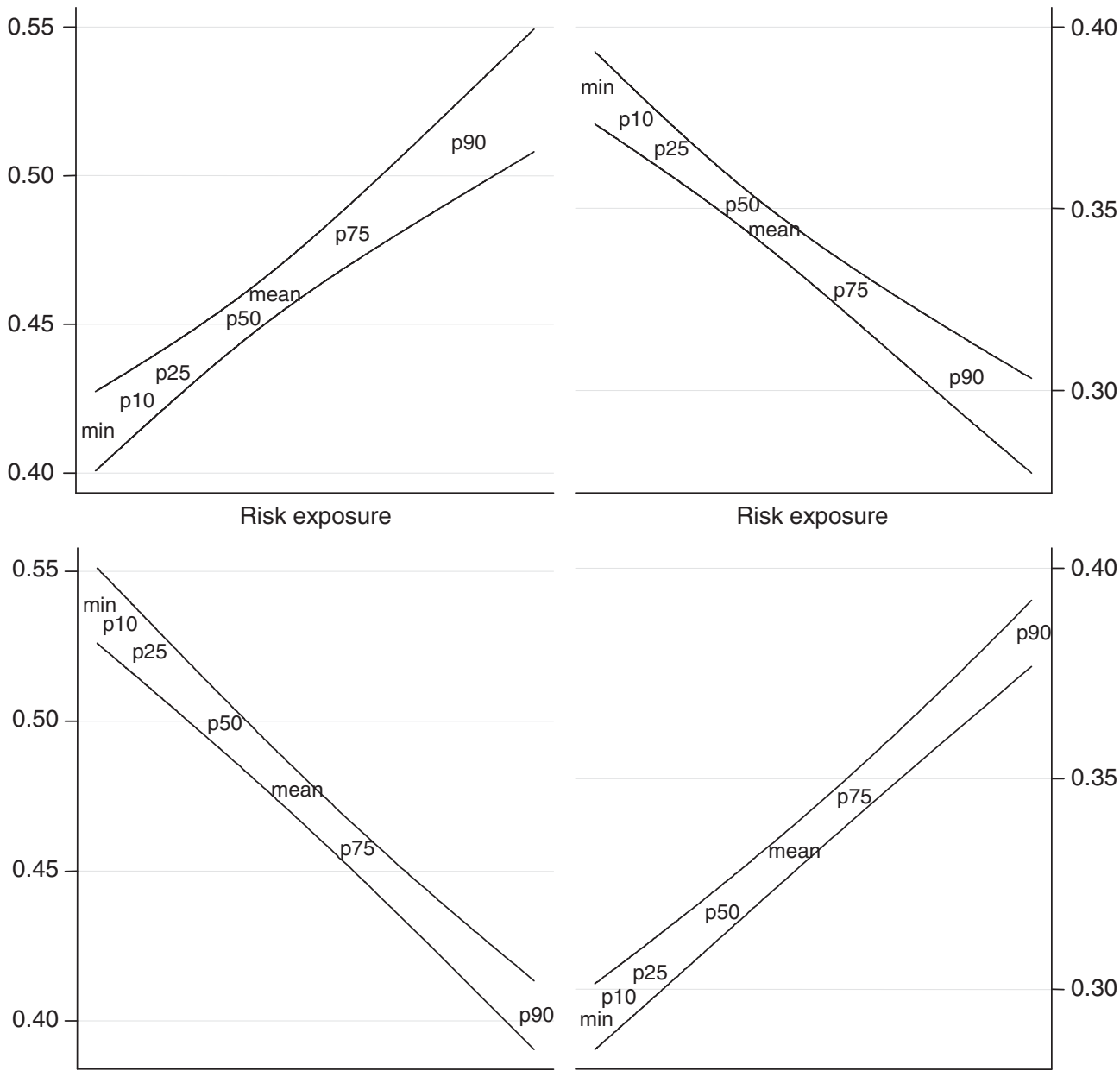

Real family income

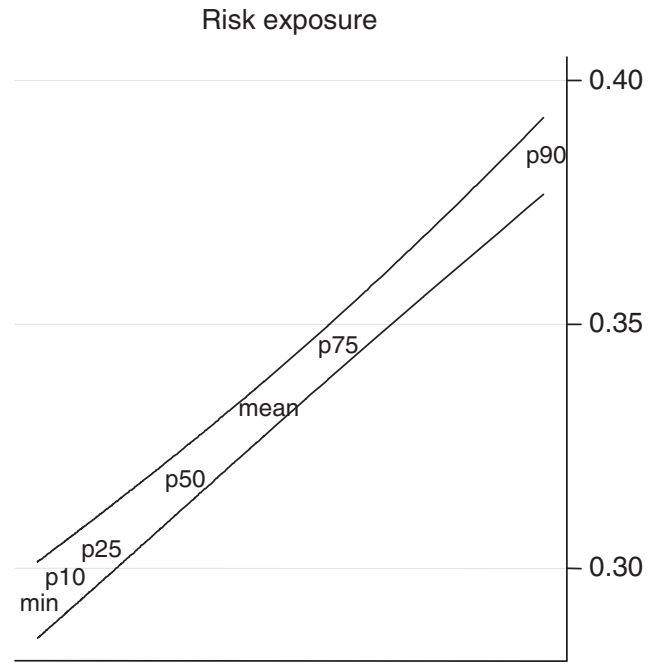

Real family income

Risk exposure (unemployment rate in \%): $\mathrm{p} 10=1.4$; mean $=5.8 ; \mathrm{p} 90=12.4$.

Family income (in $1986 \$$ ): $p 10=7,751$; mean $=34,789 ; p 90=77,099$.

Fig. 2. Predicted probabilities

Notes: Displayed are simulations of predicted probabilities of favouring redistribution (two panels on the left) and affiliating with the Republican party (two panels on the right), based on changes in risk exposure (top) and income (bottom). The simulations are based on Models 2 and 5 of Table 1, respectively, holding all other variables at their means. Point estimates are indicated by their summary statistics (i.e. min, p10, p25), while the lines are $95 \%$ confidence intervals.

For example, the top-left panel reveals that the probability of supporting redistribution increases from about 0.41 to about 0.5 when changing risk exposure from its minimum to about its 90 th percentile (this is roughly a change from close to 0 per cent unemployment to about 12.4 per cent unemployment).

The discussion above also suggests that there are 'natural' Democrats, Independents (or cross-pressured voters) and Republicans, depending on the combination of income and risk exposure. Empirically, groups line up as expected: 'natural' Democrats support redistribution more than the cross-pressured voters, while 'natural' Republicans support 

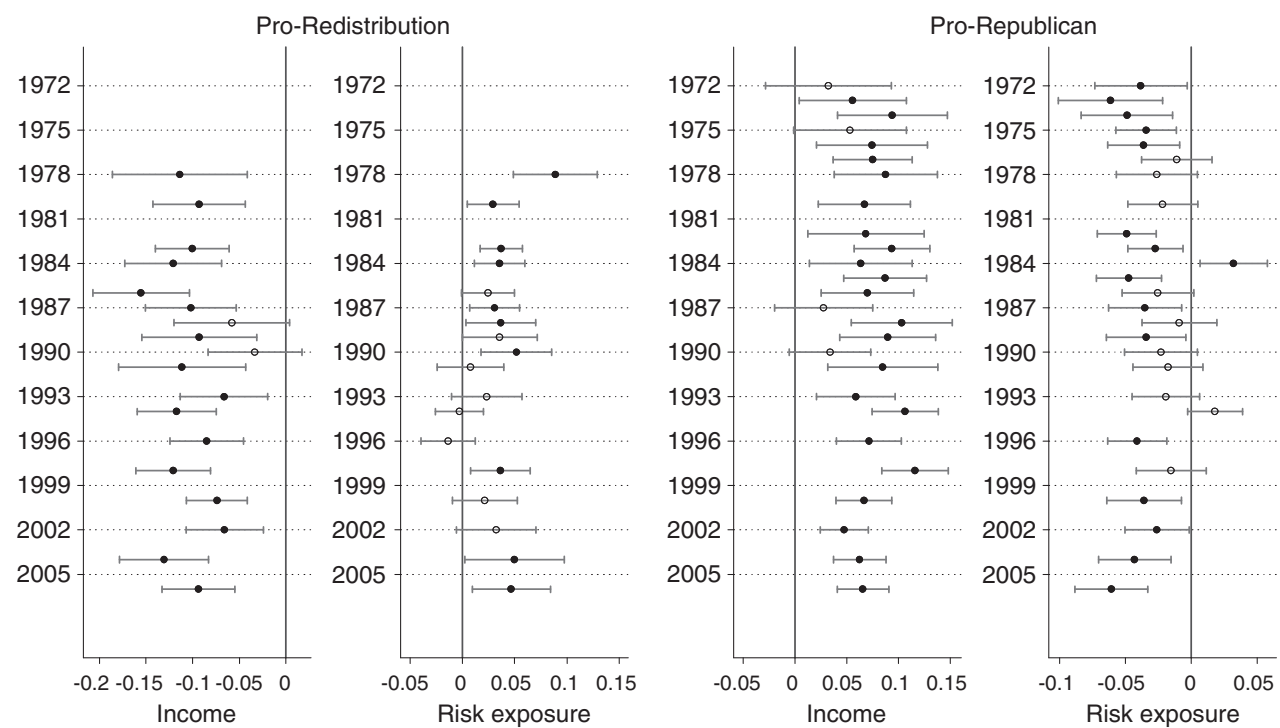

Fig. 3. Results from year-by-year estimations

Note: Displayed are the coefficients and their $90 \%$ confidence intervals from year-by-year regressions of Models 2 (left two panels) and 5 (right two panels) of Table 1. The vertical axes indicate the years, while the horizontal axes represent the coefficients of income and risk exposure, respectively. Significant coefficients are indicated by bold circles.

Data source: GSS.

it less than them. The reverse is true when it comes to the probability of affiliating with the Republicans. $^{25}$

From their statistical significance, as well as from their meaningful substantive effects, I conclude that income and risk exposure are important determinants of redistributional preferences and partisanship. This conclusion is backed by a wide range of robustness tests. ${ }^{26}$ It is, therefore, informative to explore the joint distribution of income and risk

${ }^{25}$ The predicted probabilities to be in favour of redistribution and to affiliate with the Republican party are, respectively: 'Natural' Democrats: Prob (Pro redistribution): 0.55; Prob (Republican): 0.28; 'Cross-pressured'/ 'Natural' Independents: Prob (Pro redistribution): 0.47; Prob (Republican): 0.36; 'Natural' Republican: Prob (Pro redistribution): 0.34; Prob (Republican): 0.47. The simulations are based on Models 2 and 5 of Table 1, and averaged over three groups (natural Democrats, cross-pressured voters, and natural Republicans). To arrive at these groups, both income and risk exposure are divided into tertiles (for each year). Those with lowest income and highest risk are coded as 'natural' Democrats; those with the highest income and lowest risk are coded as 'natural' Republicans, while all others are coded as 'natural' Independents. The results would be similar if the tertiles were calculated across all years, or if different cut-off points were used.

${ }^{26}$ Numerous robustness checks were carried out. The results are robust to a wide range of changes, the following factors in particular: (i) Datasets: Results are very similar if NES data are used instead of the GSS (because of the absence of a detailed occupational variable for earlier years, the analysis can only be carried out on data from 1984 onwards). (ii) Dependent variables (DVs): To ease the presentation of substantive effects, the DVs are recoded into dummy variables. Estimates on the seven-category versions of the dependent variables, using ordered logit models, lead to similar results. Furthermore, the results also hold if vote choice in presidential elections is the dependent variable. Moreover, the results of the article remain basically unchanged if a stricter definition of Democrat or Republican is chosen. (iii) Measurement of risk exposure: Occupational unemployment rates are measured with a detailed classification. The results are similar if more aggregated or different classifications are used (such as the 
exposure ('risk inequality'). Since the impact of neither income nor risk exposure changes meaningfully over time, neither of these variables alone can explain the observed process of sorting. However, in combination, they can. This compositional effect will be explored next.

\section{The Macro Level}

How are income and risk exposure jointly distributed, and how has this changed over time? The CPS can be used to generate a dataset at the (detailed or more aggregated) occupational level containing the risk exposure measure used in the micro-level analysis and each occupation's real annual wage (see Appendix for details). ${ }^{27}$ We can then look at the relationship between these two variables, and how it changes over time. For illustration, Table 2 lists twenty-two 'major groups' of occupations and interesting covariates thereof. These twenty-two broad types of occupations are obviously much less detailed than the 380 or so occupations employed in the micro-analysis above and some of the macro-analysis below, and they 'hide' a lot of heterogeneity. ${ }^{28}$ However, the aggregated data help to show the big picture.

Table 2 displays unemployment rates and wages at the major occupational group level, for 1971 and 2002. ${ }^{29}$ Occupations with particularly low unemployment rates are found in groups 25 (Education, Training, and Library Occupations), 29 (Healthcare Practitioners and Technical Occupations) and 23 (Legal Occupations). Compared to the national average of roughly 6 per cent (in the years 1971 and 2002), these major occupational groups had unemployment rates below 2 per cent (again, there is obviously quite a bit of heterogeneity across the occupations summarized in the aggregated major occupational groups). In contrast, the major occupational groups 37 (Building and Grounds Cleaning and Maintenance Occupations), 35 (Food Preparation and Serving Related Occupations)

\footnotetext{
(F'note continued)

major occupational groups displayed in Table 2 or the ISCO88 classification at various levels). To avoid results that are driven by outliers, the occupational unemployment rate variable is top-coded at its 98 th percentile. This makes no difference. More details, including the thorny issue of dealing with occupational classifications that change over time, can be found in the Appendix. (iv) Control variables: Robustness checks reveal that the results hold up if the regressions include an additional variable containing occupational wages or if other occupational concepts are included (such as class or prestige scores). (v) Income concept: Real family income is the income variable used in the micro-analysis. One could also follow MPR and employ relative income rather than absolute income, where relative income is simply the ratio of a respondent's real family income (reported in the GSS survey) to the average income in a given year. The results do not depend on this choice. Alternatively, one could use wages at the occupational level, again leading to the same conclusions (unsurprisingly, occupational wages have less explanatory power than family income). (vi) Sample: I assign retired respondents the risk exposure level of their previous occupation. Alternatively, one could restrict the sample to those in the labour force; one could also assign a respondent with a missing value on occupation of her or his spouse's occupation. Neither of these changes would change the results meaningfully.

27 I prefer to use the CPS over the GSS for the macro-analysis because the GSS is not sampled representatively with respect to the labour market indicators of interest in this article. For example, it is implausible that the GSS is representative with respect to the 380 or so occupations distinguished for the risk exposure variable.

28 These are all but one major group from the Standard Occupational Classification (SOC) (see http:// www.bls.gov/soc/socguide.htm). As in the rest of the analysis, I left out 'Military Specific Occupations' (major group 55). Within these 23 major groups, there are 96 minor groups, 449 broad occupations and 821 detailed occupations.

29 The years 1971 and 2002 span the longest possible time-range without a major change in the occupational classification. The economy-wide unemployment rate in these years is also very similar (about 5.8 per cent).
} 


\begin{tabular}{|c|c|c|c|c|c|c|c|c|c|c|c|}
\hline \multirow[b]{2}{*}{ Occupation } & \multicolumn{4}{|c|}{ Employment $^{\mathrm{a}}$} & \multicolumn{2}{|c|}{$\begin{array}{l}\text { Unemploy- } \\
\text { ment rate } \\
(\%)\end{array}$} & \multicolumn{2}{|c|}{$\begin{array}{c}\text { Annual median } \\
\text { wage (in } 2005 \text { US\$) }\end{array}$} & \multirow[b]{2}{*}{$\begin{array}{c}\text { Routine task } \\
\text { imp'ce }^{\mathrm{b}} \text { (all years) }\end{array}$} & \multirow[b]{2}{*}{$\begin{array}{l}\text { Education level } \\
\quad \text { (all years) }\end{array}$} & \multirow[b]{2}{*}{$\begin{array}{l}\text { Union members }^{\mathrm{d}} \\
\text { 1990-2002 (\%) }\end{array}$} \\
\hline & $\begin{array}{l}1971 \\
(\%)\end{array}$ & $\begin{array}{c}2002 \\
(\%)\end{array}$ & $\begin{array}{l}\text { change } \\
\text { '02-'71 }\end{array}$ & $\begin{array}{l}\text { CAG- } \\
\text { R'71-'02 }\end{array}$ & $\begin{array}{l}1971 \\
(\%)\end{array}$ & $\begin{array}{c}2002 \\
(\%)\end{array}$ & 1971 & 2002 & & & \\
\hline $\begin{array}{l}11 \text { Management } \\
13 \text { Business \& Financial }\end{array}$ & 10.1 & 11.1 & 1.0 & 0.3 & 2.0 & 3.2 & 54,093 & 55,350 & -0.8 & 5.5 & 5.3 \\
\hline $\begin{array}{l}\text { Operations } \\
15 \text { Computer \& }\end{array}$ & 1.4 & 3.8 & 2.4 & 3.3 & 2.9 & 3.3 & 49,668 & 45,387 & -1.1 & 5.0 & 6.8 \\
\hline $\begin{array}{l}\text { Mathematical } \\
17 \text { Architecture \& }\end{array}$ & 0.5 & 0.7 & 0.2 & 1.2 & 4.9 & 4.8 & 51,635 & 60,885 & -0.8 & 6.3 & 5.5 \\
\hline $\begin{array}{l}\text { Engineering } \\
19 \text { Life, Physical \& Social }\end{array}$ & 2.6 & 3.6 & 1.1 & 1.1 & 4.5 & 3.8 & 58,519 & 66,420 & -0.4 & 5.4 & 6.8 \\
\hline $\begin{array}{l}\text { Science } \\
21 \text { Community \& Social }\end{array}$ & 0.7 & 1.0 & 0.3 & 1.2 & 3.9 & 3.9 & 51,635 & 49,815 & -0.6 & 7.2 & 13.0 \\
\hline $\begin{aligned} & \text { Services } \\
& 23 \text { Legal }\end{aligned}$ & $\begin{array}{l}0.7 \\
0.4\end{array}$ & $\begin{array}{l}1.5 \\
0.9\end{array}$ & $\begin{array}{l}0.8 \\
0.5\end{array}$ & $\begin{array}{l}2.6 \\
2.9\end{array}$ & $\begin{array}{l}1.7 \\
1.6\end{array}$ & $\begin{array}{l}3.3 \\
2.1\end{array}$ & $\begin{array}{l}34,728 \\
61,470\end{array}$ & $\begin{array}{l}33,210 \\
74,390\end{array}$ & $\begin{array}{l}-1.2 \\
-1.3\end{array}$ & $\begin{array}{l}6.4 \\
6.7\end{array}$ & $\begin{array}{r}12.3 \\
4.3\end{array}$ \\
\hline $\begin{array}{l}25 \text { Education, Training \& } \\
\text { Library }\end{array}$ & 4.4 & 5.2 & 0.8 & 0.5 & 1.2 & 1.7 & 42,871 & 44,280 & -1.3 & 8.4 & 40.8 \\
\hline $\begin{array}{l}27 \text { Arts, Entert., Sports, } \\
\text { Media } \\
29 \text { Healthcare Practitioners \& }\end{array}$ & 1.1 & 1.6 & 0.5 & 1.3 & 5.6 & 6.2 & 47,209 & 40,341 & -0.3 & 4.4 & 10.3 \\
\hline $\begin{array}{l}\text { Technical } \\
31 \text { Healthcare Support } \\
33 \text { Protective Service }\end{array}$ & $\begin{array}{l}2.7 \\
1.4 \\
3.5\end{array}$ & $\begin{array}{l}4.4 \\
2.1 \\
2.7\end{array}$ & $\begin{array}{r}1.7 \\
0.7 \\
-0.8\end{array}$ & $\begin{array}{r}1.6 \\
1.4 \\
-0.8\end{array}$ & $\begin{array}{l}2.2 \\
5.9 \\
4.5\end{array}$ & $\begin{array}{l}1.5 \\
5.1 \\
5.6\end{array}$ & $\begin{array}{l}38,357 \\
19,970 \\
31,964\end{array}$ & $\begin{array}{l}48,929 \\
22,140 \\
33,210\end{array}$ & $\begin{array}{l}0.4 \\
0.1 \\
0.5\end{array}$ & $\begin{array}{l}7.0 \\
3.3 \\
3.4\end{array}$ & $\begin{array}{l}13.0 \\
13.2 \\
30.7\end{array}$ \\
\hline $\begin{array}{l}35 \text { Food Preparation \& } \\
\text { Serving Related } \\
37 \text { Building \& Grounds }\end{array}$ & 4.2 & 5.2 & 1.0 & 0.7 & 10.1 & 8.5 & 19,179 & 18,819 & 0.3 & 2.0 & 5.7 \\
\hline $\begin{array}{l}\text { Cleaning \& Maintenance } \\
39 \text { Personal Care \& Service }\end{array}$ & $\begin{array}{l}2.4 \\
3.1\end{array}$ & $\begin{array}{l}2.8 \\
2.1\end{array}$ & $\begin{array}{r}0.4 \\
-1.0\end{array}$ & $\begin{array}{r}0.5 \\
-1.2\end{array}$ & $\begin{array}{l}8.0 \\
4.9\end{array}$ & $\begin{array}{l}8.8 \\
6.2\end{array}$ & $\begin{array}{l}29,505 \\
22,896\end{array}$ & $\begin{array}{l}22,140 \\
24,354\end{array}$ & $\begin{array}{r}0.9 \\
-0.2\end{array}$ & $\begin{array}{l}2.5 \\
2.8\end{array}$ & $\begin{array}{r}16.0 \\
8.8\end{array}$ \\
\hline
\end{tabular}


TABLE 2 (Continued)

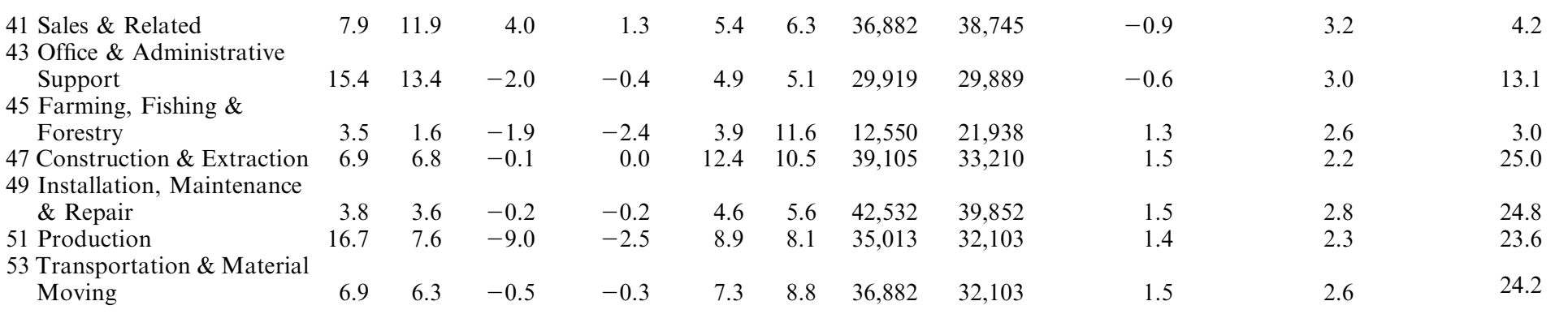

Notes: ${ }^{\mathrm{a}} \mathrm{CAGR}=$ Compound annual growth rate; ${ }^{\mathrm{b}}$ Routine task importance: $0=$ average; positive (negative) values indicate higher (lower) importance of routine tasks; 'Education level: Mean of 12 categories. Examples: 1 (Less than a High School Diploma); 6 (Bachelor's Degree); 8 (Master's Degree); 12 (Post-Doctoral Training). ${ }^{\mathrm{d}}$ Average 1990-2002 (no union data in CPS before 1990).

Data sources: CPS, but last two rows are based on ONET (see Appendix for details on ONET-based variables). 


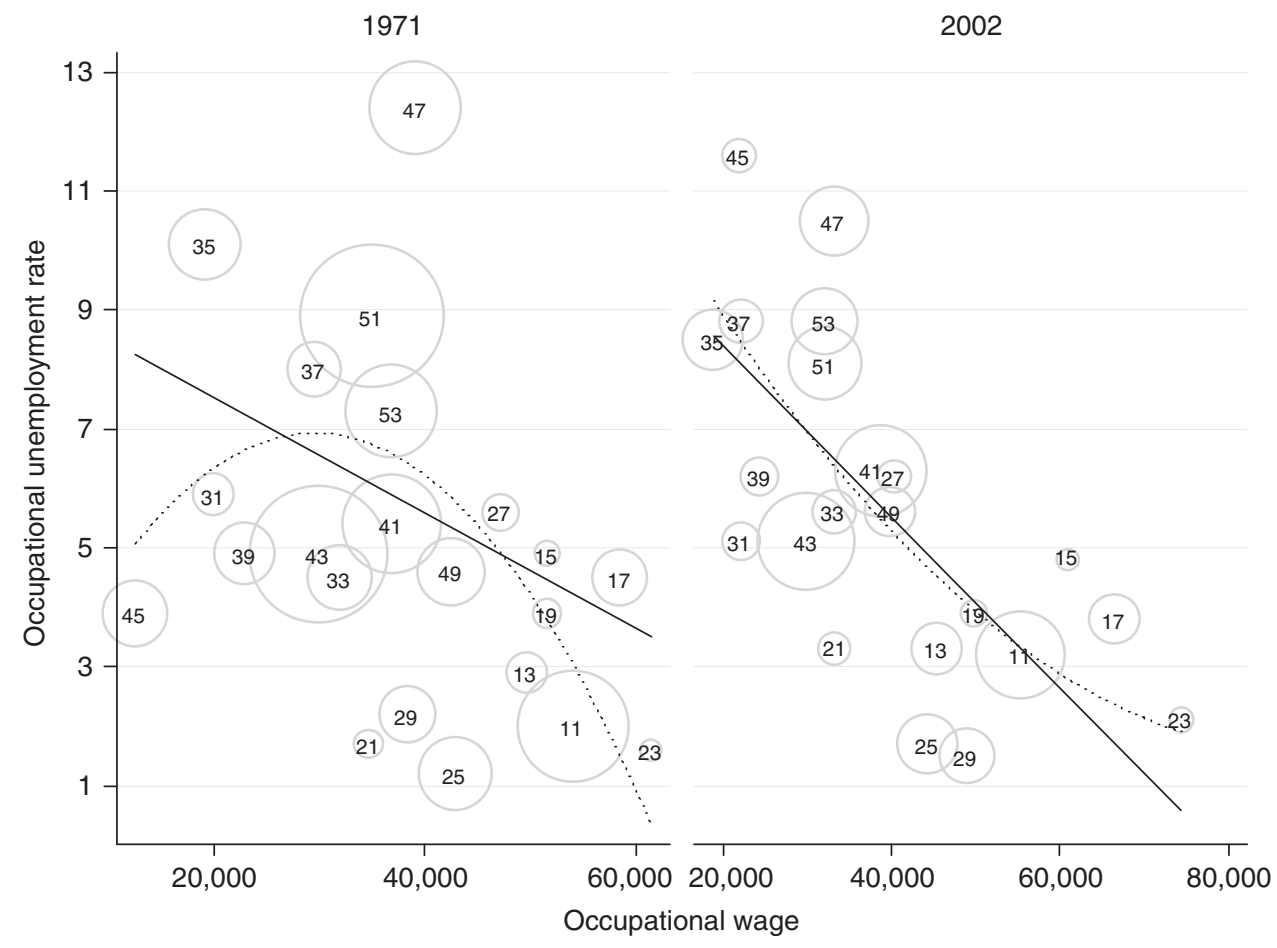

Fig. 4. Two income-risk distributions

Notes: Size of circles corresponds to size of occupational groups. Numbers correspond to major occupational groups (see Table 2). Solid lines are linear fits; dotted lines are quadratic fits.

11 Management Occupations; 13 Business and Financial Operations Occupations; 15 Computer and Mathematical Occupations; 17 Architecture and Engineering Occupations; 19 Life, Physical and Social Science Occupations; 21 Community and Social Services Occupations; 23 Legal Occupations; 25 Education, Training and Library Occupations; 27 Arts, Design, Entertainment, Sports and Media Occupations; 29 Healthcare Practitioners and Technical Occupations; 31 Healthcare Support Occupations; 33 Protective Service Occupations; 35 Food Preparation and Serving Related Occupations; 37 Building and Grounds Cleaning and Maintenance Occupations; 39 Personal Care and Service Occupations; 41 Sales and Related Occupations; 43 Office and Administrative Support Occupations; 45 Farming, Fishing and Forestry Occupations; 47 Construction and Extraction Occupations; 49 Installation, Maintenance and Repair Occupations; 51 Production Occupations; 53 Transportation and Material Moving Occupations.

Data source: CPS.

and 47 (Construction and Extraction Occupations) are characterized by particularly high unemployment rates - on average above 9 per cent (and sometimes much higher than that).

Median (and mean) wages within each major occupational group also vary widely. Pay is particularly low for workers in major occupational groups 45 (Farming, Fishing and Forestry Occupations), 35 (Food Preparation and Serving Related Occupations), 31 (Healthcare Support Occupations) and 39 (Personal Care and Service Occupations). Consistently well paid are occupations in groups 11 (Management Occupations), 15 (Computer and Mathematical Occupations), 17 (Architecture and Engineering Occupations) and 23 (Legal Occupations).

What happened to risk inequality, i.e. the relationship between occupational unemployment rates and occupational wages? We can simply correlate the two variables of main interest to get a summary measure of their relationship. To give these correlations meaning, Figure 4 
exemplifies two of the income-risk distributions which can be recovered from Table 2. In particular, Figure 4 shows the income-risk distribution for 1971 (the weighted correlation coefficient is -0.33 ) and 2002 (for which the weighted correlation coefficient is -0.66 ). ${ }^{30}$

To explore the relationship between income and risk exposure in more detail, Figure 5 shows the (weighted) correlation coefficient between income and risk exposure as well as the $t$-values from regressing income on risk exposure for each year (at the more detailed occupational level employed in the micro-part of the analysis). These summary measures of the relationship between income and risk exposure (i.e. proxies for 'risk inequality') reveal two important findings. First, the income-risk relationship is always negative. Secondly, income and risk exposure are increasingly correlated over time. In other words, over the last four decades, 'risk inequality' in the United States has been on the rise. Figure 5 may suggest otherwise, but the increase in risk inequality happened relatively gradually - although undoubtedly many of the developments occurred in the 1980s. ${ }^{31}$

Why did risk inequality increase over time? What happened in the labour market? To explore these questions, the first four columns of Table 2 provide information about employment patterns in the twenty-two major occupational groups for 1971 and 2002, and the changes over these thirty-one years. Employment in occupations summarized into major occupational group 51 (Production) decreased dramatically, from 16.7 per cent of all employment to 7.6 per cent, a decrease of 9 percentage points or a compound annual decline of 2.5 per cent. Large declines in employment shares are also found in major occupational groups 43 (Office and Administrative Support Occupations) and 45 (Farming, Fishing, and Forestry Occupations). On the other side of the spectrum are fast-growing major occupational groups, namely groups 29 (Healthcare Practitioners and Technical Occupations), 23 (Legal Occupations), 41 (Sales and Related Occupations) and 13 (Business and Financial Operations Occupations).

With respect to the variables of interest (risk exposure and income), we can observe intra-occupational changes over time (especially at detailed occupational levels) as well as inter-occupational changes. In other words, the increase in risk inequality is due to changing income and risk profiles of certain occupations, as well as due to changes in the relative size of occupations.

Figure 6 gives some insights regarding the characteristics of growing and disappearing occupations. The left-hand panel of the figure indicates changes in employment shares between 1971 and 2002 by income-risk groups of occupations. ${ }^{32}$ The share of jobs in the

30 When using the 1971 income-risk distribution with 2002 weights, the correlation coefficient is -0.45 , which suggests that the change in risk inequality is the result of both a change in the income-risk characteristics of occupations as well as a change in the size of occupations. Note that the correlation coefficients in Figure 5 differ (they are -0.32 (1971) and -0.47 (2002), respectively). The differences arise for three reasons. First, the results in Figure 5 are based on a more detailed occupational classification. Secondly, it uses mean (not median) wages (which makes no qualitative difference). Thirdly, the weights are employed and unemployed within each occupation, while above they are only the employed.

31 As detailed in the Appendix describing the CPS data, the occupational classification changes several times. One break in the series happens in 1983; even the standardized occupational classification used in this article cannot completely correct for that. However, it is possible to employ more detailed occupational classifications, such as the twenty-two 'major groups' listed in Table 2, or the twenty-seven ISCO88-2d groups. Replicating Figure 5 with these more aggregated data leads to a much smoother and even stronger pattern.

32 Occupations (at the major group level) are assigned into one of three combinations of risk exposure and income. Based on data from 1971, occupational groups are grouped in income noviles and occupational unemployment rate noviles. Adding these two variables up leads to a measure of income-risk combinations which ranges from 2 to 18 (highest income novile, lowest unemployment novile). Low income/high risk occupations are values 2 to 6 ; middle income/middle risk occupations are values 7 to 13 ; 

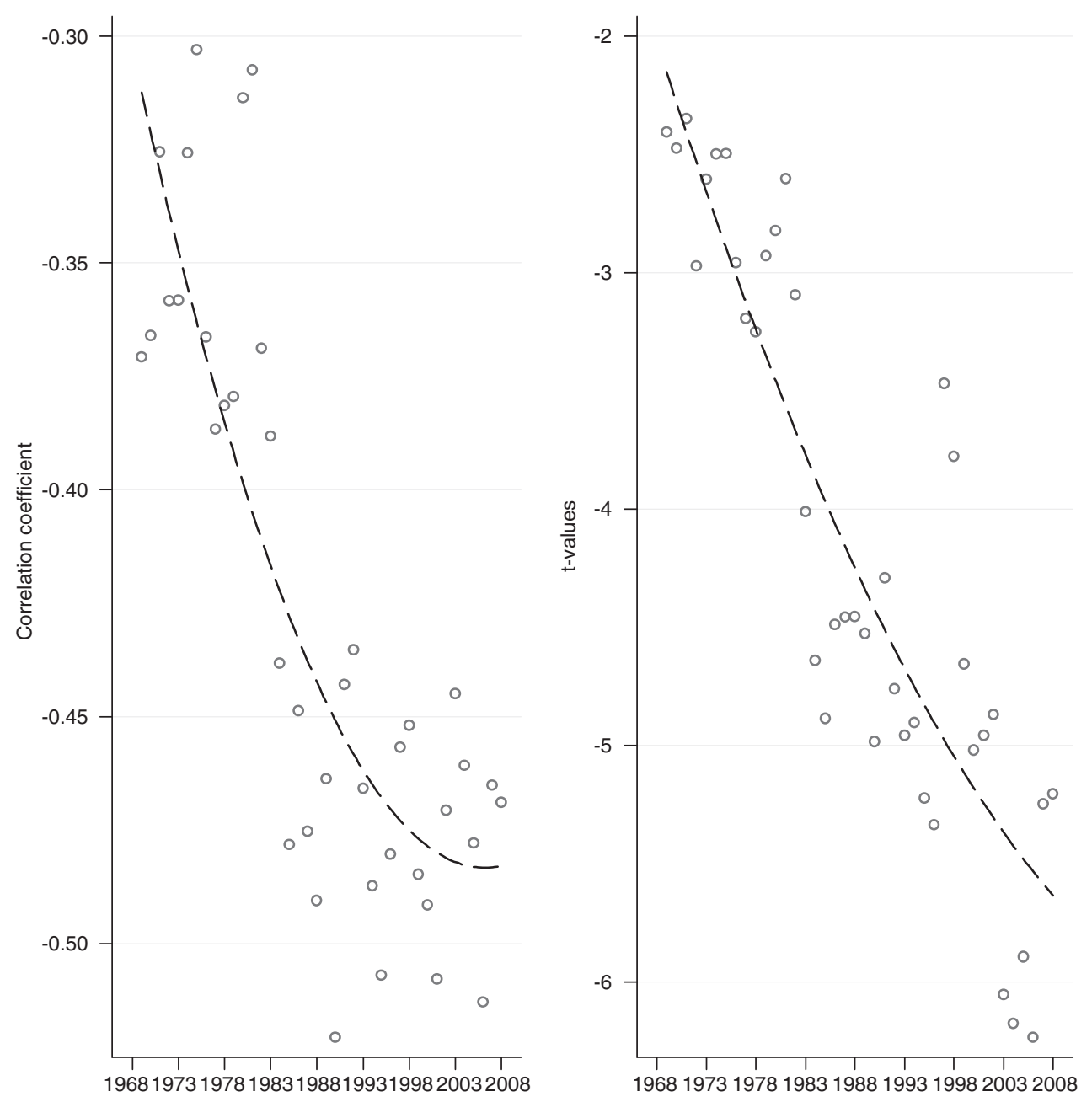

Fig. 5. Income-risk distributions over time

Notes: Plotted are two measures of the relationship between income and risk exposure, both measured at detailed occupational levels against time. The left panel shows weighted correlation coefficients (square-roots of $R^{2} \mathrm{~s}$ from regressions), while the right panel displays the resulting $t$-values when regressing income on risk exposure.

Data source: CPS.

middle of the income-risk distribution declined drastically, while the share of jobs at the top and - to a lesser degree - at the bottom of the income-risk distribution increased. Next, I briefly discuss three main suspects for this polarization of the American labour market: technological change unfavourable to 'routine' jobs; the decline in unionization; and the decline in real minimum wages. ${ }^{33}$

(F'note continued)

high income/low risk occupations are values 14 to 18. Employing the same definitions of 'natural' partisans and Independents as above as a measure of job quality would lead to similar patterns.

33 These developments are likely to be interrelated. How exogenous they are to politics is an interesting question for further research. 


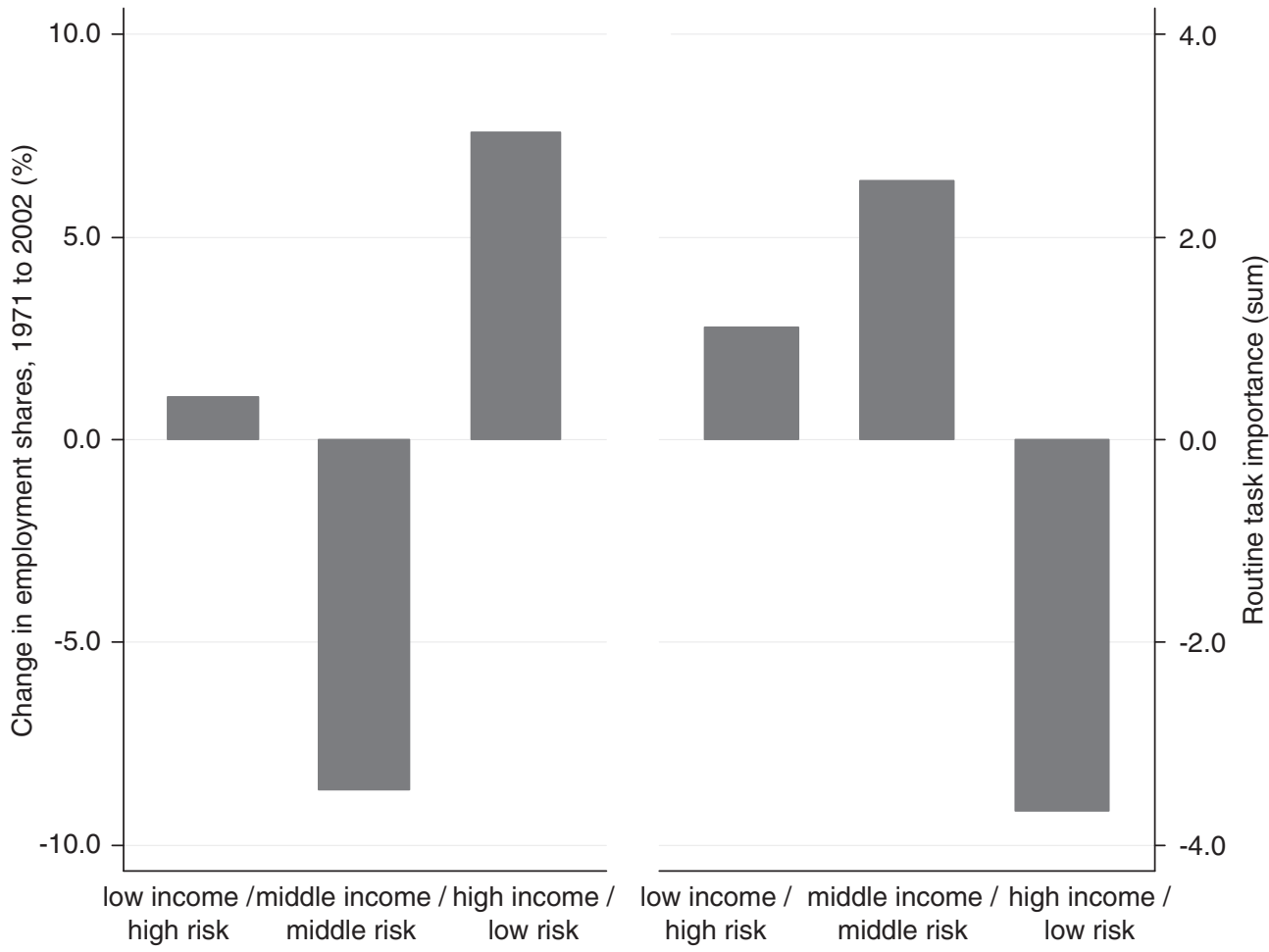

Fig. 6. Changes in employment shares, and routine task importance

Notes: Occupations (at the major group level) are assigned into one of three combinations of risk exposure and income (based on data from 1971).

Data source: CPS.

First, recent literature in sociology and economics argues that the observable pattern of 'job polarization' can be explained by the 'routinization' hypothesis. ${ }^{34}$ Of the various existing explanations for job polarization, this one seems to emerge as the most plausible. ${ }^{35}$ It suggests that technological change replaces 'routine' labour (clerical and craft jobs) in the middle of the wage distribution. This is why Table 2 includes a column containing a measure of 'routine task importance' (the table also shows the average educational level and unionization rate within each major occupational group). The right-hand panel in Figure 6 reveals that 'routinization' is also a plausible explanation for the observed increase in risk inequality: the (disappearing) middle jobs (middle income, middle risk exposure) rely disproportionally on routine tasks.

34 Job polarization has been studied by David H. Autor, Frank Levy and Richard J. Murnane, 'The Skill Content of Recent Technological Change: An Empirical Exploration', Quarterly Journal of Economics, 118 (2003), 1279-333; Erik Olin Wright and Rachel Dwyer, 'The Patterns of Job Expansions in the United States, a Comparison of the 1960s and 1990s', Socio-Economic Review, 1 (2003), 289-325; Maarten Goos and Alan Manning, 'Lousy and Lovely Jobs: The Rising Polarization of Work in Britain', Review of Economics and Statistics, 89 (2007), 118-33; Maarten Goos, Alan Manning and Anna Salomons, 'Job Polarization in Europe', American Economic Review Papers and Proceedings, 99 (2009), 58-63. To be sure, these authors focus only on income as a covariate of occupations, while I am interested in income and risk exposure.

${ }^{35}$ Goos, Manning and Salomons, 'Job Polarization in Europe', p. 58. 


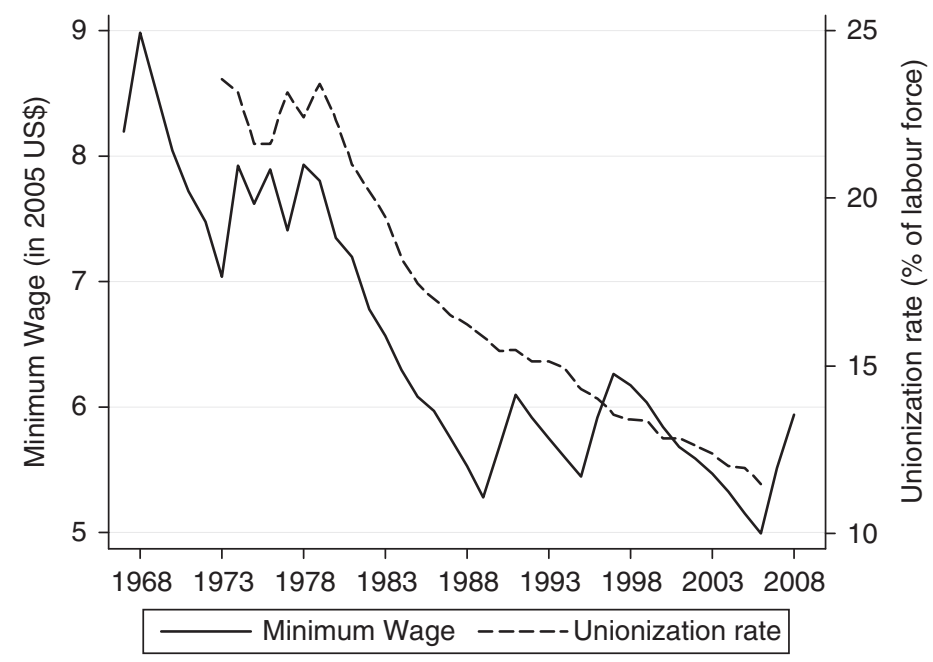

Fig. 7. Minimum wage and unionization rates

Notes: Data source for minimum wage: www.dol.gov/esa/whd/flsa

Data source for unionization rate: OECD: http://stats.oecd.org/Index.aspx?DataSetCode=U_D_D

The second and third broad labour market trends worth mentioning are the decline in unionization rates and the decline in the (real federal) minimum wage, respectively. Figure 7 documents the decrease in both variables. The real federal minimum wage dropped from about \$9 per hour in the late 1960s to about \$6 in 2008 (in 2005 dollars). The trend regarding unionization indicates that the percentage of union members (relative to the labour force) decreased from almost 25 per cent in the 1970 s to a little more than 10 per cent today. The 1980 s witnessed a particularly steep rate of decline - this is also the time period of the largest increase in risk inequality.

All three of these broad trends - routinization, decline in the minimum wage, decline in unionization - are plausible parts of an explanation for the increase in risk inequality in the last few decades in the United States. As shown above, 'routine jobs' are likely to be of the 'middle income, middle risk' kind. Likewise, unionized workers tend to enjoy higher wages and job security. Finally, increasingly low minimum wages make low income occupations particularly vulnerable. ${ }^{36}$

Whatever the reason for the increase in risk inequality, it probably has changed the partisan composition of the American electorate over time. Fewer and fewer citizens experience crosspressure from the two traits of income and risk exposure. More and more citizens have traits that should lead to pure (sorted) preferences. In other words, the relative size of the three groups identified above - 'natural' Democrats, 'natural' Independents (or cross-pressured voters) and 'natural' Republicans - changed over time. Figure 8 employs the same definition of these groups as in the micro-level analysis above and plots the percentages of 'natural' Republicans (R), 'natural' Democrats (D), the sum of these two ( $\mathrm{P}$ for 'natural' partisans = $\mathrm{R}+\mathrm{D})$ as well as the cross-pressured voters $(\mathrm{C})$ over time.

As expected from the increase in risk inequality, the figure reveals a marked sorting process of the income-risk distribution. While the proportion of people at the extremes of

\footnotetext{
${ }^{36}$ Although one could also argue that lower minimum wages may decrease unemployment rates in these jobs.
} 


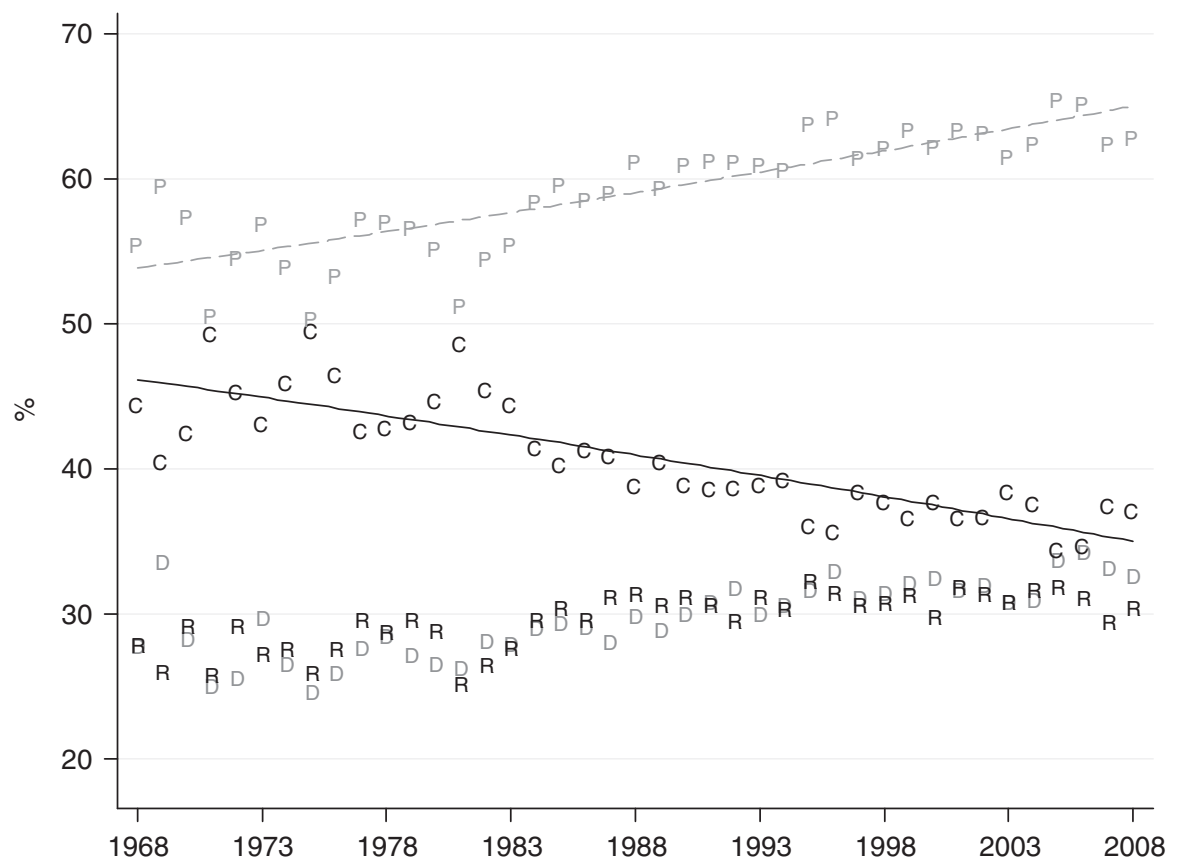

Fig. 8. The size of 'natural' constituencies over time

Notes: Shown are the percentages of the sample being classified as 'natural' Democrat (D) [lowest income tertile and highest or medium risk exposure tertile], 'natural' Republican (R) [highest income tertile and lowest or medium risk exposure tertile], or cross-pressured (C) [remaining combinations]. The three groups sum to 100 per cent. Also shown is the sum of $\mathrm{D}$ and $\mathrm{R}$, indicated by $\mathrm{P}$ (for 'natural' partisans). $\mathrm{P}$ and $\mathrm{C}$ sum to 100 per cent. The solid [dashed] line is the quadratic fit of the percentages of $\mathrm{C}[\mathrm{P}]$ against time.

Data source: CPS.

that distribution (i.e. the 'natural' Democrats and Republicans) was about the same as the proportion of people at the middle of that distribution (cross-pressured individuals, or 'natural' Independents) around 1970, they vastly outnumber them nowadays $(60 / 40) .{ }^{37}$ I believe it is this sorting process within the labour market that explains the puzzling sorting of the American electorate along partisan lines (summarized in Figure 1).

Which party, if any, has benefited from this trend? Increasing risk inequality sorts the electorate at both ends of the spectrum (and it thins out the middle). A priori, therefore, it is not clear which party benefits from such a trend. However, the increase in risk inequality has probably given an advantage to the Republicans (a potential solution to the puzzle of why a conservative party can win elections in times of sharply increasing income inequality). First, the sorting process seems to have somewhat advantaged the Republicans, as Figure 8 shows. ${ }^{38}$ The growth of 'natural' Republicans outperformed the growth of 'natural' Democrats. Secondly, the mapping from 'natural' to 'actual' partisans became somewhat stronger for Republicans and somewhat weaker for Democrats

37 The figure is based on the CPS, but the GSS would lead to similar results.

${ }^{38}$ Note that Figure 8 defines the 'natural' partisans based on tertiles that are calculated on a year-byyear basis. The tertiles could also be computed for the entire time period. The trends would be similar, but less smooth and with a stronger increase of 'natural' Rs compared to Ds. 
(overall, it is fairly constant). ${ }^{39}$ Thirdly, there is evidence that the probability of 'natural' Democrats to turn out to vote is much lower than the probability of 'natural' Republicans, and the gap is widening. ${ }^{40}$

\section{CONCLUSION}

Conventional wisdom and decades of research claim that - on average - the 'haves' sympathize with the Republican party, while the 'have-nots' prefer the Democratic party. In this article, I argue and show that the same is true when it comes to income prospects (risk exposure): the 'will-haves' tend to be pro-Republican, while the 'will-have-nots' tend to favour the Democrats. In other words, the article shows that future income - risk exposure - is a powerful factor in shaping individuals' social policy and partisan preferences (just like current income). These two traits can either be reinforcing (generating 'natural' partisans), or cross-cutting (cross-pressuring people and generating 'natural' Independents).

Consequently, risk inequality - the joint distribution of income and risk exposure - is an important concept. I show that there has been a sharp increase in risk inequality in the United States. Since the 1970s, income and risk-exposure are increasingly correlated. This has led to a sorting of the American electorate: the proportion of cross-pressured voters has decreased, while the proportion of people who can be predicted to have consistent partisan traits has increased. This sorting process can help to explain the sorting of the American electorate along partisan lines and speaks directly to the patterns sketched in Figure 1. I want to discuss briefly a few implications and limitations of my findings.

My findings suggest that there are developments at the mass level that have led to a sorting of the electorate. The conventional story goes that the increasing partisan behaviour of elites makes it easier for voters to sort themselves into partisan camps. However, my findings suggest the reverse: the sorting at the mass level gives political elites incentives for increased partisan behaviour. There is a firm 'electoral connection' to the observed sorting processes. ${ }^{41}$

From a normative perspective, I can think of many arguments why increasing risk inequality is an undesirable development for representative democracy. For example, those who are poor and risk exposed are most likely to be politically alienated. On average, about 45 per cent within this group do not vote! More generally, more extreme partisans may not perceive a fit between their preferences and the party platforms. As a final example, rising risk inequality is worsened by the 'great risk shift' - Jacob Hacker's label for the trend of privatizing the insurance of different types of risks (health, pensions, retirement, etc.). ${ }^{42}$

\footnotetext{
${ }^{39}$ It is not unproblematic to assess the mapping of 'natural' into 'actual' partisans. First, the language of 'natural' partisans is meant to communicate the main message (namely that the tails of the income-risk distribution became fatter; that we should and do find more partisans in these tails; and that therefore more citizens experience pure partisan traits) - the aim is not to maximize the statistical fit between 'natural' and 'actual' partisans. Secondly, the available data are not really appropriate for a thorough assessment (the GSS is better than the NES when it comes to occupational information; the reverse is true regarding partisanship measures; none is representative regarding income-risk distributions). Keeping these caveats in mind, the percentage of correctly predicted partisans is about 60 per cent, and fairly constant over time. The percentage of correctly predicted Republicans increased somewhat over time, while the percentage of correctly predicted Democrats decreased somewhat over time.

${ }^{40}$ Non-voters constitute between 40 and 50 per cent of those classified as 'natural' Democrats; the proportion of 'natural' Republicans who do not vote is between 10 and 20 per cent.

${ }^{41}$ Jacobson, 'Partisan Polarization in Presidential Support'.

42 Jacob S. Hacker, The Great Risk Shift: The Assault on American Jobs, Families, Health Care, and Retirement (Oxford: Oxford University Press, 2006).
} 
My account of political preference formation is quite narrow and based on purely economic considerations. Obviously, preference formation is a much more complex and complicated process. I do not deny at all that valence issues (moral values, religion) are important determinants of party ID, or that politics is not only about economic issues. Ironically, increasing risk inequality may even lead to a decrease in the importance of economic issues (since a formerly two-dimensional trait-space gets increasingly collapsed into one dimension). On the one hand, this is clearly a limitation of my approach, but, on the other hand, it also strengthens the results. The fact that preference formation is so complex stacks the deck against clear findings. If we find clear patterns despite the narrow focus on economic conditions, these patterns must be really strong.

Finally, a natural next question to ask is why risk inequality has increased over recent decades. This article offers some initial considerations and evidence that suggest that technological change unfavourable to 'routine' jobs, the decrease in the real minimum wage, and the decrease in unionization rates are plausible factors that have contributed to the increase in risk inequality. Clearly, more research is needed on the topic. Whatever their determinants, risk exposure and risk inequality may well be as important for understanding important political phenomena as income and income inequality.

\section{APPENDIX}

\section{CPS Data}

For the macro analyses as well as for deriving information on occupational unemployment, the article relies on data from the 1968-2008 March Current Population Survey (CPS) Annual Demographic Survey files. The data were extracted from the Minnesota Population Center's website. ${ }^{43}$ In choosing sample restrictions, the article closely follows the conventions in labour market research. ${ }^{44}$ The sample is restricted to civilian adults between the ages of 22 and 65 . The extraction of information about wages and unemployment by occupations was performed on a sample that was restricted to full-time full-year workers, where a worker is considered full-time if $\mathrm{s} /$ he works at least 35 hours a week and full-year if s/he works at least 40 weeks a year. For these workers, wages are the annual wage and salary earnings, divided by the number of weeks worked. The resulting weekly wage is annualized by multiplying it by 52 . Nominal wages are then deflated using a consumer price index. Top-coded wage income data were multiplied by $1.45 .{ }^{45}$ Observations where the worker is working without pay or is self-employed are excluded (the exclusion of the selfemployed is an unfortunate necessity).

In order to standardize the occupational categories over time, the article follows Meyer and Osborne. ${ }^{46}$ Since 1968 , the CPS codes occupations in fairly detailed classifications. However, these change over time. CPS uses SOC1960 definitions (the 1960 definitions of the Standard Occupational Classification, SOC) in 1968-70; SOC1970 definitions in 1971-82; SOC1980 definitions in 1983-91; SOC1990 definitions in 1992-2002; and SOC2000 definitions starting in 2003. The GSS data report respondents' occupations in SOC1970 and SOC1980 codes. Meyer and Osborne suggest a 'crosswalk' that translates each of the different SOC codes into a standardized occupational classification with 389 different categories.

\footnotetext{
${ }^{43}$ Miriam King et al., Integrated Public Use Microdata Series, Current Population Survey: Version 2.0. (Machine-Readable Database). (Minneapolis: Minnesota Population Center (producer and distributor), 2009). http://cps.ipums.org

${ }^{44}$ Most directly, I follow Zvi Eckstein and Éva Nagypál, 'The Evolution of U.S. Earnings Inequality: 1961-2002', Federal Reserve Bank of Minneapolis Quarterly Review, 28 (2004), 10-29. See their Appendix A.

${ }^{45}$ Following Lawrence F. Katz and Kevin M. Murphy, 'Changes in Relative Wages, 1963-1987: Supply and Demand Factors', Quarterly Journal of Economics, 107 (1992), 35-78.

${ }_{46}$ Peter B. Meyer and Anastasiya M. Osborne, 'Proposed Category System for 1960-2000 Census Occupations,' BLS working paper, no. 383 (2005). I am very grateful to the authors for providing me with various syntax files.
} 
Distinguishing so many categories makes the estimated unemployment rates less robust, simply because they potentially rely on only a few observations (despite the 100,000 to 160,000 observations in the CPS). Therefore, the occupational unemployment rates are top-coded at the 98th percentile. Moreover, more aggregated occupational classifications were also employed; by and large, the results are very similar when different classifications are employed. ${ }^{47}$

\section{Occupational Unemployment Rates and Subjective Job Insecurity}

Regarding the relationship between (objective) risk exposure and subjectively perceived job security, it can be shown that occupational unemployment rates are a good predictor of perceived job security, captured by a variety of survey items. In particular, the GSS data include six items that proxy perceived job security in a relatively straightforward way. ${ }^{48}$ When regressing each of these perceived job security variables on occupational unemployment rates and a set of year dummies, it turns out that people who feel that their job is insecure are likely to be employed in occupations with high unemployment rates, i.e. objective risk exposure is a significant predictor of subjective job insecurity.

\section{Measurement of Routine Task Importance}

To construct a variable of the importance of routine tasks within an occupation, I follow recent literature in labour market economics ${ }^{49}$ and rely on the 'Occupational Information Network' (ONET); see www.onetcenter.org. One part of ONET consists of variables related to 'worker characteristics', defined as 'enduring characteristics that may influence both performance and the capacity to acquire knowledge and skills required for effective work performance'. These variables are based on survey results from job incumbents who are asked how important certain characteristics

${ }^{47}$ Occupational unemployment rates can be calculated using different classifications, and at different levels of detail. The following classifications were employed for robustness tests: ILO's 'International Standard Classification of Occupations 1988' (ISCO88) at the 1-, 2-, 3- and 4-digit level, distinguishing 9, 26, 98 and 238 different types of occupations, respectively; an aggregated version of the standardization due to Meyer and Osborne, distinguishing twenty-two different occupations; and the occupational classification employed in the NES, distinguishing seventy-one different occupations. Furthermore, the unemployment rates were calculated both in total and by gender. This partially builds on a 'crosswalk' constructed by Paul Lambert (see http://www.cf.ac.uk/socsi/CAMSIS/occunits/us90toisco88v2.sps).

${ }^{48}$ The following survey items tap perceived job security: (1) Thinking about the next 12 months, how likely do you think it is that you will lose your job or be laid off - very likely, fairly likely, not too likely, or not at all likely? [JOBLOSE; $N=13,960$ ] (2) (a) Would you please look at this card and tell me which one thing on this list you would most prefer in a job? (b) Which comes next? (c) Which is third most important? (d) Which is fourth most important? B. No danger of being fired [JOBSEC; $N=9,916$ ] (3) Now, I'm going to read you another list of statements about your main job. For each, please tell me if the statement is very true, somewhat true, not too true, or not at all true with respect to the work you do. K. The job security is good. (Answer categories: very true; somewhat true; not too true; not at all true) [JOBSECOK; $N=1,658$ ] (4) Please respond to the following statements based on your experience during the past 12 months unless otherwise specified, with reference to your current place of employment only. L. At work, job security is good. (Answer categories: very true; somewhat true; not too true; not at all true) [GDJOBSEC; $\mathrm{N}=1,604]$ (5) For each statement about your main job below, please circle one code to show how much you agree or disagree that it applies to your job. A. My job is secure. (Answer categories: strongly agree; agree; neither agree nor disagree; disagree; strongly disagree) [RSECJOB $=1,480$. (6) On the following list, there are various aspects of jobs. Please circle one number to show how important you personally consider it is in a job: A. Job security? (Answer categories: very important; important; neither important nor unimportant; not important; not important at all) [SECJOB; $\mathrm{N}=1,543$ ]. The samples were restricted to those in employment.

${ }^{49}$ I broadly follow Goos, Manning and Salomons, 'Job Polarization in Europe'. They, in turn, build on the following two contributions: Autor, Levy and Murnane, 'The Skill Content of Recent Technological Change: An Empirical Exploration'; David H. Autor and David Dorn, 'Inequality and Specialization: The Growth of Low-Skill Service Jobs in the United States', (unpublished paper, 2007). 
are for her or his job, where importance ranges from 1 (not important at all) to 5 (extremely important).

Using a crosswalk provided by the National Crosswalk Service Center, ${ }^{50}$ it is possible to translate the 800 or so occupations coded by ONET into the above-mentioned major occupational groups. I selected a set of variables which relate to the importance of 'Psychomotor Abilities' (Arm-Hand Steadiness; Manual Dexterity; Finger Dexterity; Control Precision; Multi-limb Co-ordination; Response Orientation; Rate Control; Reaction Time; Wrist-Finger Speed; Speed of Limb Movement). A factor analysis applied to these variables (using averaged values) clearly leads to a one-factor solution and high factor loadings. These loadings range from 0.71 (Finger Dexterity) to 0.95 (Control Precision). The factor scores (based on regression scoring) are reported in Table 2. High values indicate greater importance of routine tasks.

\footnotetext{
${ }^{50}$ http://webdata.xwalkcenter.org/ftp/DOWNLOAD/xwalks/SOC2000xISCO88.zip.
} 